www.jmscr.igmpublication.org

Impact Factor (SJIF): 6.379

Index Copernicus Value: 79.54

ISSN (e)-2347-176x ISSN (p) 2455-0450

crossrefDOI: https://dx.doi.org/10.18535/jmscr/v6i9.28

Journal Of Medical Science And Clinical Research

IGM Publication

An Official Publication of IGM Publication

\title{
Analysis of caeserian section rate using robson's classification in a tertiary care hospital of eastern Odisha
}

\author{
Authors \\ Tapasi Pati, Satyabhama Marandi*, Sanjukta Mohapatra \\ Department of Obstetrics and Gynaecology, IMS \& SUM Hospital, Siksha O Anusandhan Deemed to be \\ University, K8, Kalinga Nagar, Bhubaneshwar, Odisha \\ *Corresponding Author \\ Dr Satyabhama Marandi \\ Associate Professor, Dept of Obstetrics and Gynaecology, IMS and SUM Hospital, Bhubaneswar, India \\ Email: drsatya0@gmail.com, Cell: +919437518278
}

\begin{abstract}
Introduction: With increased safety of operative deliveries the caesarean section rates have been increasing steadily all over the world. Analysis of the caesarean section rate of a centre would allow insight into preventable causes of the rising problem.

Objective: This retrospective study was undertaken to analyse the indications of caesarean deliveries in one year period from 18 Jun 2017 to 17 Jun 2018 using Robson's Ten Group Classification System and to find out the preventable causes of caesarean section.

Method: All patients who delivered during this period were identified based on labour room delivery register. Their records were analysed on basis of age, parity, risk factors, mode of delivery, intra partum events and indication of caesarean section. Data was entered in Excel sheet and classified as per Robson's Ten Group Classification System.

Results: Caesarean section rate was $52.7 \%$ during the study period. Caesarean section was lowest in Group 3(10.31\%) and highest in Group 6(92.68\%). Group 2 made the highest contribution to overall Caesarean section rate (23.93\%). Analysis of indications in Group 2 showed that Oligohydramnious and Post ART pregnancies were the two modifiable indications where decision towards Caesarean section was much liberal.

Conclusion: Strategies to reduce the caesarean section rate should concentrate on Primigravida who are getting admission to the Hospital for safe confinement i.e not in labour. Hospital needs to review its policy regarding intervention in oligohydramnious and post ART pregnancies. Strict Policy guidelines on Induction of labour protocols and trial of labour in the previous caesarean cases will improve the situation. Keywords: Caesarean Section, Robson's Classification, Indications of Caesarean Section.
\end{abstract}

\section{Introduction}

According to recent data, the caesarean section rate is constantly increasing beyond the recommended level of $10-15 \%$ by World Health Organisation $^{(1)}$. Caesarean section is usually performed to ensure safety of the mother and child under obstetric risks. In the last two decades, caesarean section rate has increased to almost two fold in both developed and developing countries like India. In 2010, the incidence was around 
$8.5 \%$ but it has increased upto $58 \%$ in some states like Telengana ${ }^{(2)}$. There is an increased concern regarding rising trends of caesarean section. All are concerned regarding the future problems of the surgery. There are many reasons for the rise out of which some are enumerated below:

(a) Increased Institutional delivery

(b) Good intra-partum monitoring

(c) Good anaesthesia

(d) Availability of powerful antibiotics

(e) Increase in no of private hospitals

(f) Advanced neonatal care facilities

(g) Less time consuming and more rewarding surgery. It takes hours to deliver vaginally but only 30 minutes to deliver abdominally

Benefits of abdominal delivery performed in an indicated case are many so are the disadvantages in unnecessary cases. Long term sequelae are Postpartum morbidity, chance of PID, Endometriosis, Adenomyosis, decreased fecundity, increased risk of abortion and ectopic pregnancy and increased chances of placental abnormalities like placenta previa and placenta accreta in subsequent pregnancies. All these complications have made us to think twice. In present scenario we need self-introspection. We need to review our performance and modify wherever we can.

Most caesarean sections are classified according to the indications for surgery ${ }^{(3,4)}$. But then it becomes difficult to compare the rates with others as they may not be using the same terminologies. In 2001 Dr Michael Robson of National Maternity Hospital, Dublin proposed the Ten Groups Classifications System (TGCS). These ten groups are mutually exclusive, simple to use and read yet include the total sample ${ }^{(5)}$.

TGCS is used worldwide and WHO applied the Robson 10 group Classification to a multi country data set $^{(6)}$. The Robson 10 Group Classification Systems facilitates comparative analyses of Caesarean Sections between different centres nationally, internationally and globally.

Hence we at our centre planned to classify and analyse the Caesarean rate according to Robson
10 Group Classification System and formulate our strategy for future development depending upon the result. The Robson 10 Groups Classifications System allows a critical analysis of Caesarean Section according to characteristics of pregnancy.

\section{Method}

The study was conducted for a period of one year, 18 Jun 17 to 17 June 18 at IMS and SUM Hospital, Bhubaneswar which is a tertiary care centre attached to a medical college in the capital city of Odisha. All the ladies who have delivered during this period in the labour ward were included in the study. All relevant Obstetric information like parity, mode of previous delivery, previous obstetric history, gestational age, onset of labour (induced or spontaneous), type of delivery, weight of the baby and condition of baby at birth along with any complications of mother or baby were recorded and then entered into Microsoft excel sheet. Results calculated at the end of the study period and analysed according to Robson's ten group classification (Table - 1).

Table 1: Robson's ten Group Classification of caesarean sections

\begin{tabular}{|l|l|}
\hline No & Groups \\
\hline 1 & Nulliparous, Single cephalic, $>37$ weeks in spontaneous labor \\
\hline 2 & $\begin{array}{l}\text { Nulliparous, Single cephalic, > 37 weeks induced or CS } \\
\text { before labor }\end{array}$ \\
\hline 3 & $\begin{array}{l}\text { Multiparous (excluding previous CS), Single cephalic, > 37 } \\
\text { weeks in spontaneous labor }\end{array}$ \\
\hline 4 & $\begin{array}{l}\text { Multiparous (excluding previous CS), Single cephalic, > 37 } \\
\text { weeks induced or CS before labor }\end{array}$ \\
\hline 5 & Previous CS, Single cephalic, $>37$ weeks \\
\hline 6 & All nulliparous breeches \\
\hline 7 & All multiparous breeches (Including previous CS) \\
\hline 8 & All multiple Pregnancies (Including previous CS) \\
\hline 9 & All abnormal lies (Including previous CS ) \\
\hline 10 & All Single Cephalic, <36 wks (Including previous CS) \\
\hline
\end{tabular}

\section{Results}

The total number of deliveries during study period was 1601 out of which vaginal deliveries were 757 and Caesarean Section 844. Hence the overall Caesarean section rate calculated for SUM hospital during the specified period was $52.7 \%$. Analysis of caesarean rate done according to Robson's ten group classification and contribution of each group to overall caesarean rate is shown separately (table2). 
Group 2 (nulliparous, induced labour group) has the greatest contribution to the total caesarean section rate $(23.93 \%)$ followed by group 5(previous CS group) has contributed $22.63 \%$. Group 1 (nulliparous, term, spontaneous deliveries) has contributed third highest $(21.56 \%)$ to the total CS rate. Group 3 i.e singleton term multiparous excluding previous caesarean in spontaneous labour group is the lowest rate $(10.31 \%)$.

Group 1 and 2 consist of nulliparous women. Commonest causes for admission without labour was oligohydramnious (45/202 i.e. $22.3 \%)$ and post ART pregnancy (30/202 i.e14.8\%) mostly those conceived following IVF-ET or ICSI, out of which 27 had elective caesarean section which contributes to $13.4 \%$ of caesarean section in the group. Further analysing these cases we found that post IVF pregnancies were frequently associated with maternal medical disorders like hypertension, GDM, hypothyroidism etc. which is not taken into consideration while arranging data according to TGCS. Further analysis of oligohydramnious cases which contributes $22.3 \%$ of caesarean section in the group and it is found that most were elective caesarean section and done before start of labour.
Group 5 (women with previous caesarean scar) was further analysed according to the indications. Data are insufficient regarding trial of labour after caesarean (TOLAC). Out of 213 cases of repeat caesarean section, 129 cases opted for elective caesarean section at term. Out of 88 who went into labour only 22 delivered vaginally. 62 were emergency caesarean section for various indications like fetal distress, impending rupture, previous 2 caesarean sections in labour, meconium staining of liquor etc.

Group 3 (singleton term multiparous women with spontaneous onset of labour) has the lowest incidence of caesarean section rate (10.31\%). Group 6 which consist of nulliparous singleton breech is the highest contributor (92.68\%). As it comprises $2.37 \%$ of the total number of deliveries, it contributes $4.5 \%$ to overall caesarean section rate.

Group 7 (singleton breeches in all multiparous women including previous CS) and Group 9(singleton pregnancy with abnormal lie including previous CS) are among the two second highest caesarean section rate $(87.5 \%)$ but contributes only $1.65 \%$ of overall caesarean rate. This analysis made us to understand that the areas of improvement are in post ART pregnancy, oligohydramnious, post-caesarean pregnancies.

Table 2 Overall CS rate (\%) 844/1601 (52.7\%)

\begin{tabular}{|c|c|c|c|c|c|}
\hline Group & $\begin{array}{l}\text { Robson's ten group classification } \\
\text { Criteria }\end{array}$ & $\begin{array}{l}\text { No. of cs over total } \\
\text { no. of women in } \\
\text { each group }\end{array}$ & $\begin{array}{l}\text { Relative size } \\
\text { of group }(\%)\end{array}$ & $\begin{array}{l}\text { Cs rate in } \\
\text { each } \\
\text { group }(\%)\end{array}$ & $\begin{array}{c}\text { Contribution to } \\
\text { overall cs rate } \\
(\%)\end{array}$ \\
\hline 1. & $\begin{array}{l}\text { Nulliparous, Single } \\
\text { spontaneous labor }\end{array}$ & $182 / 532$ & $\begin{array}{l}532 / 1601 \\
(33.23 \%)\end{array}$ & $\begin{array}{c}182 / 532 \\
(34.21 \%)\end{array}$ & $\begin{array}{l}182 / 844 \\
(21.56 \%)\end{array}$ \\
\hline 2. & $\begin{array}{l}\text { Nulliparous, Single cephalic, > } 37 \text { weeks induced or } \\
\text { CS before labor }\end{array}$ & $202 / 251$ & $\begin{array}{l}251 / 1601 \\
(15.67 \%)\end{array}$ & $\begin{array}{l}202 / 259 \\
(77.99 \%)\end{array}$ & $\begin{array}{l}202 / 844 \\
(23.93 \%)\end{array}$ \\
\hline 3. & $\begin{array}{l}\text { Multiparous (excluding previous CS), Single cephalic, } \\
>37 \text { weeks in spontaneous labor }\end{array}$ & $20 / 199$ & $\begin{array}{l}199 / 1601 \\
(12.42 \%)\end{array}$ & $\begin{array}{c}20 / 194 \\
(10.31 \%)\end{array}$ & $\begin{array}{l}20 / 844 \\
(2.37 \%) \\
\end{array}$ \\
\hline 4. & $\begin{array}{l}\text { Multiparous (excluding previous CS), Single cephalic, } \\
\text { > } 37 \text { weeks induced or CS before labor }\end{array}$ & $31 / 50$ & $\begin{array}{l}50 / 1601 \\
(3.12 \%) \\
\end{array}$ & $\begin{array}{c}31 / 50 \\
(62.0 \%) \\
\end{array}$ & $\begin{array}{l}31 / 844 \\
(3.67 \%) \\
\end{array}$ \\
\hline 5. & Previous CS, Single cephalic, > 37 weeks & $191 / 213$ & $\begin{array}{l}213 / 1601 \\
(13.30 \%)\end{array}$ & $\begin{array}{c}191 / 213 \\
(89.67 \%)\end{array}$ & $\begin{array}{l}191 / 844 \\
(22.63 \%)\end{array}$ \\
\hline 6. & All nulliparous breeches & $38 / 41$ & $\begin{array}{l}38 / 1601 \\
(2.37 \%)\end{array}$ & $\begin{array}{c}38 / 41 \\
(92.68 \%)\end{array}$ & $\begin{array}{l}38 / 844 \\
(4.50 \%)\end{array}$ \\
\hline 7. & All multiparous breeches (Including previous CS) & $14 / 16$ & $\begin{array}{l}14 / 1601 \\
(0.99 \%)\end{array}$ & $\begin{array}{c}14 / 16 \\
(87.50 \%) \\
\end{array}$ & $\begin{array}{l}14 / 844 \\
(1.65 \%) \\
\end{array}$ \\
\hline 8. & All multiple Pregnancies (Including previous CS) & $34 / 44$ & $\begin{array}{l}44 / 1601 \\
(2.74 \%)\end{array}$ & $\begin{array}{c}34 / 44 \\
(77.27 \%)\end{array}$ & $\begin{array}{c}34 / 844 \\
(4.03 \%)\end{array}$ \\
\hline 9. & All abnormal lies (Including previous CS ) & $14 / 16$ & $\begin{array}{l}16 / 1601 \\
(0.99 \%)\end{array}$ & $\begin{array}{c}14 / 16 \\
(87.50 \%)\end{array}$ & $\begin{array}{c}14 / 844 \\
(1.65 \%)\end{array}$ \\
\hline 10. & All Single Cephalic, <36 wks (Including previous CS) & $118 / 239$ & $\begin{array}{l}239 / 1601 \\
(14.92 \%)\end{array}$ & $\begin{array}{c}118 / 239 \\
(49.37 \%)\end{array}$ & $\begin{array}{c}118 / 844 \\
(13.98 \%)\end{array}$ \\
\hline
\end{tabular}


Table 3

\begin{tabular}{|l|c|c|c|}
\hline Indication & Elective & Emergency & Total \\
\hline Fetal distress & 00 & 21 & 21 \\
\hline Failed induction & 00 & 28 & 28 \\
\hline Non progress of labour & 00 & 23 & 23 \\
\hline Meconium stained liquour & 00 & 05 & 05 \\
\hline Cephalo-pelvic disproportion & 05 & 06 & 11 \\
\hline Placental insufficiency & 03 & 02 & 05 \\
\hline Nonreactive CTG & 02 & 04 & 06 \\
\hline Post ART pregnancy & 27 & 04 & 30 \\
\hline Oligohydramnious & 33 & 15 & 45 \\
\hline Polyhydramnious & 01 & 00 & 01 \\
\hline Placenta previa & 02 & 01 & 03 \\
\hline Maternal medical disorders & 14 & 05 & 19 \\
\hline Others & 05 & 00 & 05 \\
\hline Total & 92 & 110 & 202 \\
\hline
\end{tabular}

Table 4 (analysis of Group 1 cases according to indication)

\begin{tabular}{|l|c|}
\hline Indication & Frequency \\
\hline Fetal distress & 76 \\
\hline Non progress of labour & 05 \\
\hline Meconium stained liquour & 33 \\
\hline Cephalo-pelvic disproportion & 36 \\
\hline Nonreactive CTG & 01 \\
\hline Post ART pregnancy & 09 \\
\hline Oligohydramnious & 09 \\
\hline Polyhydramnious & 01 \\
\hline Placenta previa & 03 \\
\hline Maternal medical disorders & 09 \\
\hline
\end{tabular}

\section{Discussion}

It has been noted that no agreement has been reached on an appropriate Caesarean section rate ${ }^{(6,7,8,9)}$. However WHO and US Healthy People 2000 initiative suggested $10-15 \%$ as the optimal caesarean section rate ${ }^{(10,11)}$. Still it is difficult to set an optimal rate target for referral institute. It has been suggested that caesarean section rate should not be considered at too high or too low rather they are appropriate or not after taking in to consideration of all relevant information ${ }^{(12)}$. What matters most is that all women who need caesarean sections receive them (WHO statement $2010)^{13}$.

In our study the overall caesarean section rate for the one year study was $52.7 \%$ which is too high considering WHO recommendation (10-15\%). Ours is a Tertiary care Health Centre dealing mostly with referred cases. This rate is comparable to some other Tertiary Care Hospitals attached to different Medical Colleges over the country. PSG Institute Coimbatore showed in their study an average caesarean section rate of $41.5 \%$.

The most common contributor of caesarean section were Group 2 i.e nulliparous women not in labour admitted for confinement. Among these women most prevalent cause of caesarean section was Oligohydramnios and post ART pregnancies. Our hospital is attached to a Medical College. We have an ART Centre where ongoing pregnancy rate is more than $60 \%$. Again the NICU discharge rate of healthy babies is more than $88 \%$. Hence women conceived with ART procedure usually liberalised for elective caesarean section. Most of the time post IVF pregnancies are associated with other maternal or Foetal complications like PIH, Preeclampsia, GDM, Placenta previa, reduced Foetal movement, Non reassuring NST, IUGR etc. In such conditions it becomes difficult not to concern about fetal welfare in today's small family norm which may have changed the delivery in favour of caesarean section. Proper counselling and trial of labour in such case may reduce primary caesarean rate.

Though RCOG recommended that all women previously delivered by an lower segment caesarean section should be offered an opportunity to labour during next pregnancy by promoting a trial of labour (TOLAC), less enthusiasm is expected for TOLAC may be because caesarean is doctor friendly, TOLAC is not. So it should be recommended that every unit must plan protocol for labour in patient with previous caesarean section. Previous caesarean group made the second largest contributor to the total number of caesarean section (22.63\%) in our study. Appropriate selection of patients and counselling in the antenatal period can increase the number of patients who undergo Trial of labour after caesarean section. Robson recommended that Group 6,7,8,9 and 10 should not be targeted in trying to reduce the caesarean section rate because the relative risks are too high for minimal reduction in the numbers. 


\section{Conclusion}

After careful analysis, we concluded that the caesarean rate of our institution need to be modify and strategy should aim at modifying the management of nulli-parous women. Hospital needs to review its policy regarding management of oligohydramnious cases as well as post ART pregnancies. This will reduce the primary caesarean rate and hence the repeat caesarean will automatically reduce. There is also need of enhancing vaginal birth after caesarean by trial of labour in scarred uterus.

\section{Competing interests}

The author have no conflict of interests to declare.

\section{References}

1. Appropriate technology for birth. Lancet. 1985;2(8452):436-7.

2. T.Radhakrishnan et al.increasing Trend of Caesarean rates in India:Evidence from NHFS-4.JMSCR.august2017;5(08);2616726176.

3. Thomas $\mathbf{J}$.The National Sentinel Caesarean Section Audit Report. London. RCOG Press 2001

4. Turcot L, Marcoux S, Fraser WD. Multivariate analysis of risk factors for operative delivery in Nulliparous women. Canadian early amniotomy study group. Am J Obst Gynae 1997; 176: 395-402.

5. Robson MS. Can we reduce the caesarean section rate? Best Pract Res Clin Obstet Gynaecol. 2001;15(1):179-94.

6. Betran AP, Gulmezoglu AM, Robson M, Merialdi M, Souza JP, Wojdyla D, et al. WHO global survey on maternal and perinatal health in Latin America: classifying caesarean sections. Reprod Health. 2009;6:1

7. Gibbons L, Belizan JM, Lauer JA, Betran AP, Merialdi M, Althabe F. Inequities in the use of cesarean section deliveries in the world. Am J Obstet Gynecol. 2012; 206:331.

8. Ecker JL, Frigoletto FD. Cesarean delivery and the risk-benefit calculus. $\mathrm{N}$ Engl $\mathrm{J}$ Med. 2007;356:885-8.

9. Fuglenes D, Øian P, Kristiansen IS. Obstetricians' choice of cesarean delivery in ambiguous cases: is it influenced by risk attitude or fear of complaints and litigation? Am J Obstet Gynecol. 2009; 200:e1-e8.

10. WHO. Appropriate technology for birth. Lancet. 1985;24: 4360-4370.

11. Department of Health and Human Services; Centers for Disease Control and Prevention; National Center for Health Statistics. Healthy People 2000: national health promotion and disease prevention objectives: Full report, with commentary (DHHS publication no.(PHS) 91-50212). Washington: Government Printing Office.

12. Robson MS. Can we reduce the caesarean section rate? Best Pract Res Clin Obstet Gynecol. 2001;15:179-94.

13. Schulz KF, Altman DG, Moher D. CONSORT 2010 statement: updated guidelines for reporting parallel group randomised trials. BMC medicine. 2010 Dec;8(1):18. 